\title{
Supporting Quality Instruction: Building Teacher Capacity as Instructional Designers
}

Jen Vanek, World Education

A predominant narrative about adult education during the COVID-19 pandemic has been about how teachers, under unprecedented hardship, endeavored to work in new ways, drawing on technology tools and digital resources to sustain instruction when they could not meet learners in person (Belzer et al., 2020). Though teaching and learning at a distance did not resonate well with all teachers and learners, those who persisted did realize notable success in continuation of work and learning (Vanek, 2021). In order to succeed, teachers had to embrace working in entirely new ways - especially in the way they planned or designed instruction.

There was sufficient success in the field that, by spring of 2021, a common and very salient conversation among teachers and adult education leaders alike was about how to define "the new normal." That is, how the field might leverage or build on instructional innovations (e.g., flexibility of programming, focus on digital skills development, personalization of learning) without, what was acknowledged by many as, the unprecedented level of work for teachers during the pandemic. Perhaps the answer lies in finding ways for teachers to more quickly make efficient and sound decisions about digital resources and technology integration. I offer here a suggestion -- encouraging structured use of technology integration frameworks and strategies to evaluate the effectiveness of their decision decisions and implementation. Doing so can help teachers build on what they learned as practitioners during the pandemic and build their capacity to design technology-rich instruction that meets the needs of diverse learners.

\section{Looking Back in Order to Move Ahead}

Though there were efforts made to leverage technology to enhance and extend learning opportunities in adult literacy, basic academic skills, and ESOL programming prior to the pandemic, many programs found it difficult to prioritize that work. Common challenges included lack of resources to support students, students' limited access to devices, and both practitioners' and learners' skills and comfort learning with digital resources (Vanek et al., 2020). There is little reported research on the level of use of technology in adult education classrooms (Lister et al., 2014); however, federally reported data on participation in distance education does exist, as reported in NRS Table $4 \mathrm{C}$, and shows this reticence reflected in the percentage and number of learners participating in distance education prior to the pandemic.

Participation in distance education was consistently low in the years leading up to the 
pandemic. In program years 2016-2017 and 20172018 , they represented just $3.8 \%$ of all learners. In 2018-2019, the number rose very slightly to $4 \%$. Across these years, data show that distance learners performed nearly as well or better than non-distance learners (National Reporting System for Adult Education, n.d.).

2019-2020 NRS data show a marked increase in distance learners (up to $16 \%$ of all learners), which included 3 months of the pandemic. However, MSC attainment for distance learners dropped from about $45 \%$ in the previous year to $39 \%$ in the 2019-2020 program year (National Reporting System for Adult Education, n.d.), which includes the earliest months of the pandemic and can likely be accounted for by the rapid rush to distance learning by programs and teachers who were ill-prepared to help learners succeed. Though it should be noted that these data offer a limited perspective for a number of reasons, ${ }^{1}$ this jump in distance education hours shows that it may have been a previously under-utilized but promising option for adult education.

Beyond the formal distance education reported on in NRS Table $4 \mathrm{C}$, programs also relied on remote live instruction during the pandemic, which was an entirely new enterprise for many of them. A nationwide survey on instructional shifts during the early months of the pandemic showed that half of instruction was provided synchronously and remotely (Belzer et al., 2020). This monumental shift accomplished within a matter of weeks further indicates the potential of programs to use digital technologies to enhance and extend learning opportunities.

\section{Teacher's Decisions about Digital Technology and Resource Integration}

How was any success possible? There was a deluge of professional development throughout the pandemic (World Education, 2020), and programs provided paid time for teachers to collaborate to craft sharable activities and lesson plans (Vanek et al., 2021). Because hardly anyone had prior experience delivering live remote instruction (including those providing the professional development!), they perhaps relied on what instructional design scholars Lachheb et al. (2021) refer to as "core judgements."

These strategies provided enough support to launch pandemic-era instruction; however, many of the decisions were hastily made (out of necessity) and complicated the work of teachers. Moving forward, use of a framework, especially when teachers are new to crafting technology-rich activities or lessons (Cherner et al., 2021; Kimmons et al., 2018; Tunjera et. al, 2019), can mitigate the tendency for ad hoc decision making around technology use in instruction. Over time, a teacher's past experience and lessons learned from productive failure and successes can help establish confidence and design capacity that leads to more sound choices for technology integration (Ertmer et al., 2010).

\section{Tech Integration Models or Frameworks}

There are several popular models that ask teachers to consider why they are choosing a particular technology or digital resource and then reflect on the impact of the choice on either their instruction or student learning (Kimmons et al., 2018). Models that I have seen used in adult education settings include TPACK, SAMR, and the Triple E Framework.

1 Table 4 C likely under-reports actual engagement in distance education because 1) not all states report distance education time, 2) states use it to report participation only for learners engaged in distance education as a majority of their time, and 3) states likely reported less time in 2020 because OCTAE essentially relaxed reporting requirements during the pandemic, "The U.S. Departments of Education and Labor (Departments) will not make any determinations of performance success or failure based on PY 2019 performance data, submitted by October 1, 2020." (Program Memorandum Octae (No. 20-3), 2020) 


\section{TPACK}

The Technological, Pedagogical and Content Knowledge (TPACK) framework (illustrated in Figure 1), illustrates teacher knowledge about the content they teach, required pedagogies, and how to use technology in support of instruction. The framework guides teachers to consider their awareness in each area with the goal of making sound choices about technology use (Mishra \& Koehler, 2006).

\section{FIGURE 1. TPACK model (Mishra \& Koehler, 2006, p. 1024)}

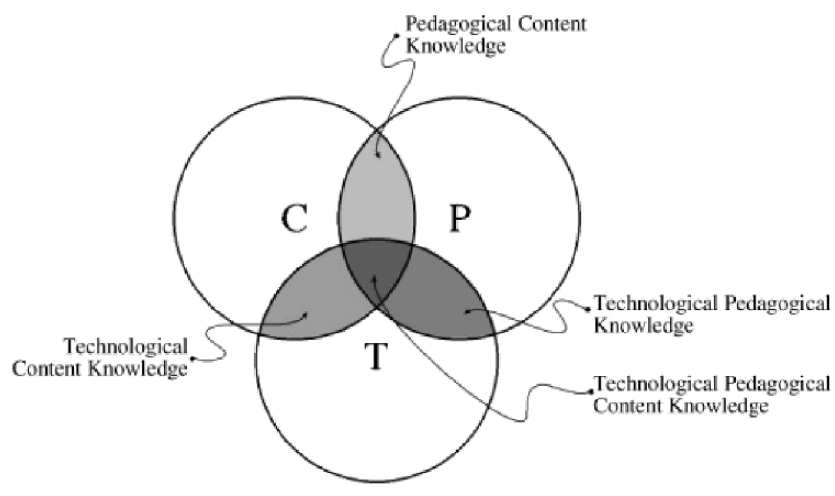

\section{SAMR Model}

Puentedura's Substitution, Augmentation, Modification, and Redefinition (SAMR) model (SAMR, n.d.) moves beyond teacher knowledge to illustrate the impact of a technology, whether it has the potential to enhance or transform instruction. At the substitution level, a technology has no impact on instruction, and the student task remains the same. With augmentation, instruction is likely enhanced and improved, but the teacher could accomplish the activity with either a different technology or none at all. Transformation is the goal at the opposite end of the spectrum, where the use of the technology completely modifies, or at the redefinition level, the technology choice creates opportunities for new ways of teaching and learning. (SAMR, n.d.). See Figure 2 for more information.
FIGURE 2. The SAMR Model (as shown on SAMR Model, n.d.)
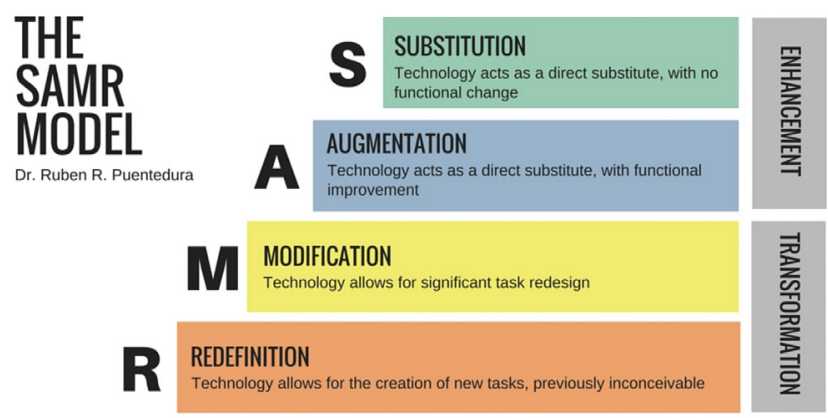

\section{The Triple E Framework}

The Triple E Framework helps us understand how students learn because of a chosen technology. Kolb (2017) writes that technology is used for three reasons: to support student engagement, enhance learning, and provide a means to extend learning outside of class. A perfect lesson might offer use of technology that hits on all three purposes. The Triple E Framework is unique among these models because it focuses on what students do with technology. Figure 3 illustrates the model.

\section{FIGURE 3. Triple E Framework (Kolb, 2017)}

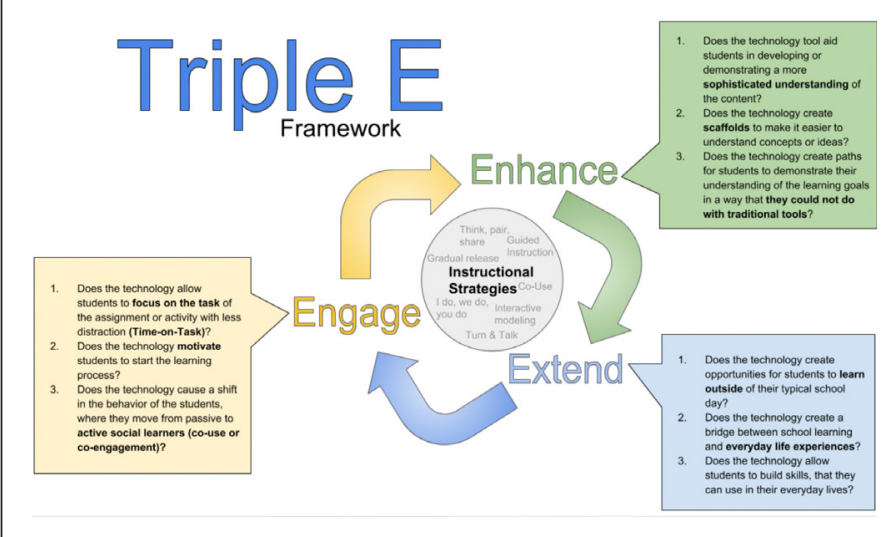

\section{Which Model Is Best?}

Essentially teachers need to think about their focus for reflection and planning. Is it the teacher, the technology, or the learning? The infographic shown in Figure 4 can help teachers differentiate among them. 
FICURE 4. Technology integration framework summary

\begin{tabular}{|c|c|}
\hline $\begin{array}{l}\text { TPACK } \\
\text { Focus on the } \\
\text { teacher }\end{array}$ & $\begin{array}{l}\text { - Measure of teacher knowledge and } \\
\text { preferences } \\
\text { - Helpful for understanding technology tool and } \\
\text { instructional goal alignment and tensions }\end{array}$ \\
\hline SAMR & - Potential impact of a technology on an activity \\
\hline $\begin{array}{l}\text { Focus on the } \\
\text { activity }\end{array}$ & $\begin{array}{l}\text { - Helpful for understanding how a technology } \\
\text { will shape instruction }\end{array}$ \\
\hline Triple E & - Potential of a technology to shape a learner's \\
\hline $\begin{array}{l}\text { Focus on } \\
\text { learning }\end{array}$ & $\begin{array}{l}\text { experience } \\
\text { • Helpful for understanding why it supports } \\
\text { learning }\end{array}$ \\
\hline
\end{tabular}

Different frameworks resonate well with different teachers-depending on planning style, comfort, and past experience.

\section{Developing Pedagogical Design Capacity}

Drawing on any of the frameworks presented above to scaffold design and technology integration decisions can help teachers gain confidence and a sense of how a given technology or digital resource will play out in use. Over time, teachers can develop their pedagogical design capacity (PDC), a teacher's capacity to rely on current knowledge and other resources to adapt or construct curriculum and materials to meet the specific learning needs of a given context (Brown, 2009). Teachers with developed PDC can deconstruct and reassemble instructional resources in order to design pedagogically beneficial materials and activities. Teachers with low PDC require support if they are to meet their instructional goals. A teacher builds PDC over time, after experiencing success and productive failure drawing on or making use of their own media with different and diverse groups of students. As teachers develop PCD, they can more nimbly encounter, evaluate, and adapt or create digital resources and resources (Vanek, 2017).

\section{Evaluating Design and Technology Integration Decisions}

For teachers to further develop confidence, or their PDC, incorporating digital technologies and resources, they need to have a sense of whether or not their choices have created opportunities for learning. It is challenging to disentangle the impact of a particular digital resource or integrated technology on learning, given the multitude of variables at play when evaluating instruction, but scholars in the field of instruction design point to a range of strategies that might be helpful. These include formative evaluation in development of resources (Calhoun et al., 2021; Morrison, 2019; Ritzhaupt, 2021), teacher self-evaluation and ample integration of formative assessment in the instructional sequence (Wiley et al., 2021), and collaboration with peers (Hokansen, 2013).

\section{Teacher Self-Evaluation}

Even if materials are designed based on prior research and there are opportunities for summative evaluation measuring learning outcomes, teachers need to engage in their own evaluation to see short term learning goals are met. Teachers also need to ensure that learners have adequate access to the technologies required for learning - and know how to use them.

RISE Analysis. Continuous improvement of digital resources is critical when putting instruction online (Wiley et al., 2021). Because teachers make a multitude of decisions when designing instruction, not every single decision can be validated by extensive study, so teachers need to continuously engage in hypothesizing about how instruction, activities, resources employed will maximize learning (Wiley et al., 2021). 
The Resource, Inspection, Selection, and Enhancement (RISE) analysis can support decision making by identifying learning outcomes where students had seemed highly engaged with instructional materials, but simultaneously performed poorly on aligned assessments (Wiley et al., 2021). To do a RISE analysis, teachers first review assessment items to ensure they, too, are aligned, then reflect on why learners might be struggling, looking for any mismatches and lack of alignment or confusing elements of the assessment, activities, or materials.

Design Critique. The evaluation process need not be completely internal and done independently but benefit when done with peers. "Design critique" depends on working in collaboration with peers or more knowledgeable others to access formative feedback that can move design forward or redirect it (Hokansen, 2013). It can take the form of a "desk critique," a conversation between the teacher or designer and a friendly critic, where both learn more about the design and extend their skills. A benefit to peer critique for a teacher is that it can help them deepen their capacity for self-reflection and their own read of the work with a critical eye. Involving more teachers in a PLC provides an opportunity for group critique - where teachers provide critique and learn together.

Including Access as an Evaluation Measure. In their recent work for USAID, Murray et al. (2021) similarly direct teachers to center evaluation on learning objectives and learner engagement in activities. Their Reach, Engagement, and Outcomes (REO) model measures characteristics through both formative and summative evaluation. The inclusion of "reach," a learner's access to devices, the internet, cellular networks, and digital learning content, in the REO model is important. The lack of access is a barrier to adult basic education; only about half of households earning less than $\$ 30,000$ per year have a computer (Anderson \& Kumar, 2019) and half of all Americans say they are not confident in using technology to learn (Mamedova et al., 2018). Evaluation must include analysis of whether or not students have the devices and internet access required to make use of instructional technologies and the developed resources.

\section{An Example}

In our work at the EdTech Center@World Education, we are supporting the use of technology integration and evaluation and noted how this positively impacts the work of teachers. A new course, Building an EdTech Strategy Toolkit Template, designed by my colleague Jeff Coumas together with OTAN's Penny Pearson, walks teachers through a structured consideration of strategy for technology tool adoption. Starting with learner-centered factors - including learners' access, motivations, and skill levels - we ask teachers to consider the "what," "why," and "how" for any technology adoption decision to be leveraged for evidencebased strategies. As a culminating activity for course completion, teachers implement their chosen strategies (use of a technology for a specific purpose) and then reflect on their decision. An open access resource is available to help any teacher move through this process. The template integrates a mix of the three technology integration frameworks and evaluation strategies described above and is available here: https:// bit.ly/best-strategy-template. Teachers can use it to document their decisions guided by these framing prompts. See Figure 5. 
FIGURE. 5: Elements of a tech integration strategy

\begin{tabular}{|c|c|c|}
\hline WHAT & WHY & HOW \\
\hline $\begin{array}{l}\text { Provide the name of } \\
\text { the strategy. } \\
\text { - Concisely explain } \\
\text { what learners } \\
\text { do as part of this } \\
\text { strategy. }\end{array}$ & $\begin{array}{l}\text { Provide a salient } \\
\text { reason the strategy } \\
\text { is effective. This may } \\
\text { include: } \\
\text { - Eases a process } \\
\text { - Addresses barriers } \\
\text { - Enhances or } \\
\text { extends learning } \\
\text { - Builds critical } \\
\text { skills }\end{array}$ & $\begin{array}{l}\text { Identify the type of } \\
\text { tool you would use } \\
\text { to implement the } \\
\text { strategy. } \\
\text { - Provide specifics } \\
\text { around how } \\
\text { to leverage } \\
\text { that particular } \\
\text { tool within } \\
\text { instruction. }\end{array}$ \\
\hline
\end{tabular}

Through the course, we are attempting to provide a fluid process linking evidence-based technology integration frameworks with structured reflection and evaluation. Over time, we hope to see teachers internalize it, to develop their core judgements or pedagogical design capacity and the need to depend less on use of a structured process.

\section{Conclusion}

The breadth of instructional and communication technologies, and the digital resources employed to carry out distance education and remote instruction, have the potential to extend the reach of our adult education programs, offering more flexible personalized opportunities for busy adult learners and boosting the digital literacy skills for those who had previously faced barriers of access to digital technologies. However, planning is more complex when adding in technology integration and digital resources and challenges that arise when integrating technology without planning can absolutely derail a lesson. Some initial structure provided by technology integration frameworks and employing formative evaluation strategies can lead to solid design decisions and can help teachers make them more fluidly over time. This is the way to build a "new normal." 


\section{References}

Anderson, M. , \& Kumar, M. (2019). Digital divide persists even as lower-income Americans make gains in tech adoption. Pew Research Center. http://www.pewresearch.org/facttank/2018/10/19/5-charts-on-global-views-of-china/

Belzer, A., Leon, T., Patterson, M., Rhodes, C., SalasIsnardi, F., Vanek, J., Webb, C., \& Willson-Toso, B. (2020). Covid-19 rapid response report from the field. ProLiteracy. https://www.literacynewyork.org/ documents/Covid-19/COVID-19-Report.pdf.

Calhoun, C., Sahay, S., \& Wilson, M. (2021). Instructional design evaluation. In J. K. McDonald \& R. E. West (Eds.), Design for learning: Principles, processes, and praxis (pp. 1-17). EdTech Books. https:// edtechbooks.org/id

Cherner, T., \& Mitchell, C. (2021). Deconstructing EdTech frameworks based on their creators, features, and usefulness. Learning, Media and Technology, 46(1), 91-116. https://doi.org/10.1080/17439884.2020.1773852

Ertmer, P. A., \& Ottenbreit-Leftwich, A. T. (2010). Teacher technology change. Journal of Research on Technology in Education, 42(3), 255-284. https://doi.org/10.1080/15391523.2010.10782551

Hokanson, B. (2013). Design critique. In J. McDonald \& R. West (Eds.), Design for learning: Principles, processes, and praxis (pp. 85-104). EdTech Books. https:// edtechbooks.org/id

Kimmons, R. , Hall, C. How useful are our models? Pre-service and practicing teacher evaluations of technology integration models. TechTrends, 62, 29-36 (2018). https://doi.org/10.1007/s11528-017-0227-8

Kolb, L. (2017). Learning first, technology second: The educator's guide to designing authentic lessons. ISTE.

Lachheb, A. , \& Boling, E. (2021). The role of design judgment and reflection in instructional design. In J. McDonald \& R. West (Eds.), Design for learning: Principles, processes, and praxis (pp. 1-12). EdTech Books.

Mamedova, S., Pawlowski, E., \& Hudson, L. (2018). A description of U.S. adults who are not digitally literate (No. NCES2018-161; Statistics in Brief). U.S. Department of Education. https://nces.ed.gov/ pubs2018/2018161.pdf
National Reporting System for Adult Education. (n.d.). Aggregate reports by year, 2016-2020. U.S. Department of Education. https://nrs.ed.gov/rt

Program memorandum OCTAE (No. 20-3). (2020, March). U.S. Department Of Education Office Of Career, Technical, And Adult Education. www2.ed.gov/ about/offices/list/ovae/pi/AdultEd/octae-programmemo-20-3.pdf

Ritzhaupt, A. (2021). ADDIE explained: An open educational resource for the educational technology community. http://www.aritzhaupt.com/addie_ explained/

SAMR Model. (n.d.). Technology is learning. https://sites. google.com/a/msad6o.org/technology-is-learning/ samr-model

Tunjera, N., \& Chigona, A. (2019). Teacher educators' appropriation of TPACK-SAMR Models for 21st century pre-service teacher preparation. International Journal of Information and Communication Technology Education, 16(3), 126-140. https://doi.org/10.4018/ijicte.2020070110

Vanek, J. (2017). Migrant adult learners and digital literacy: Using DBR to support teaching and learning. University of Minnesota. https://conservancy.umn.edu/ handle/11299/190483

Vanek, J., Simpson, D. , \& Goumas, J. (2020). IDEAL distance education and blended learning handbook (7th ed.). EdTech Books. https://edtechbooks.org/ideal_dl_ handbook

Vanek, A. J., Webber, A. A., Kallenbach, S., Singh, N., Uvin, J., González, C., \& Crowe, A. (2021). Promising practices for adult remote ESOL. https://edtech. worlded.org/wp-content/uploads/2020/03/esolpromisingpractices-1.pdf

World Education. (2020). What we learned: Adult education's response to emergency remote teaching and learning. https:// edtech.worlded.org/wp-content/uploads/2020/07/WEIfor-BMCF-Adult-Ed-COVID19-Response-8.2020.pdf

Wiley, D., Strader, R., \& Bodily, R. (2021). Continuous improvement of instructional materials. In J. McDonald \& R. E. West (Eds.), Design for learning: Principles, processes, and praxis. EdTech Books. https:// edtechbooks.org/id/continuous_improvement 